\title{
TINJAUAN YURIDIS TANGGUNGJAWAB PENGEMUDI DAN PERUSAHAAN ANGKUTAN ATAS PENGANGKUTAN BARANG MELALUI ANGKUTAN DARAT (Studi CV. Belawan Indah)
}

\author{
Jinner Sidauruk ${ }^{1}$, Grace M. C. Lumbantobing ${ }^{2}$ \\ ${ }^{1,2}$ Program Studi Ilmu Hukum \\ Universitas HKBP Nommensen, Medan-Sumatera Utara-Indonesia \\ e-mail: jinner.sidauruk@uhn.ac.id
}

\begin{abstract}
$C V$ Belawan Indah as a company engaged in the field of freight services is also not free from problems arising from mistakes of drivers and transport companies. In discussing the problems in this thesis needed a method of data collection, to obtain data with research. The research in question is the research method of library research and interviews that is collecting material obtained from primary data and secondary data. The data obtained will be analyzed normatively which is descriptive qualitative so that it illustrates the reality. Based on research results obtained at $C V$. Belawan Indah that the driver and the transport company are jointly responsible by disadvantage arising in the freightage via truck transportation to delays, damage, and lose the goodsin each operation of transportation and efforts of the owner of the disadvantage in the freightage the goods can file a claim for compensation through a consumer and business dispute resolution agency or the so-called BPSK or through a court of law within the general court.

Keywords: Transportation, Disadvantage
\end{abstract}

\begin{abstract}
Abstrak
CV Belawan Indah sebagai perusahaan yang bergerak dalam bidang jasa pengangkutan barang juga tidak luput dari permasalahan yang timbul akibat kesalahan pengemudi dan perusahaan angkutan. Dalam membahas permasalahan dalam skripsi ini diperlukan metode pengumpulan data, untuk memperoleh data dengan penelitian. Penelitian yang dimaksud adalah dengan metode penelitian studi kepustakaan (Library Research), dan wawancara yaitu mengumpulkan bahan yang diperoleh dari data primer dan data sekunder. Data-data yang diperoleh akan dianalisis secara normatif yang bersifat kualitatif deskriptif sehingga menggambarkan kenyataan yang ada. Berdasarkan hasil penelitian yang diperoleh di CV.Belawan Indah bahwa pengemudi dan perusahaan angkutan bertanggung jawab secara bersama-sama atas kerugian yang timbul dalam pengangkutan barang melalui darat akibat keterlambatan, kerusakan, dan kehilangan barang pada setiap penyelenggaraan pengangkutan dan upaya pemilik barang atas kerugian dalam pengangkutan barang dapat mengajukan tuntutan ganti kerugian melalui lembaga penyelesaian sengketa konsumen dan pelaku usaha atau yang disebut BPSK atau melalui peradilan yang berada di lingkungan peradilan umum.

Kata kunci: Pengangkutan, Kerugian
\end{abstract}

\section{A. Pendahuluan}

Pengangkutan barang di Indonesia terdiri dari darat, laut dan udara. Hal ini dikarenakan Negara Indonesia adalah negara kepulauan yang tediri dari ribuan pulau kecil dan besar. Selain itu Indonesia juga memiliki wilayah perairan yang luas yang terdiri dari sebagian besar laut, 
sungai dan danau. Untuk mempermudah hubungan atau interaksi antara masyarakat membutuhkan suatu sarana transportasi yang menjangkau seluruh wilayah Indonesia. Bidang transportasi merupakan sarana yang sangat penting dan strategis dalam memperlancar roda perekenomian, menunjang pembangunan berbagai sektor dan lain sebagainya. ${ }^{1}$

Perjanjian pengangkutan menimbulkan hak dan kewajiban pada kedua belah pihak, yang dimana hak dari pengangkut ialah menerima biaya pengangkutan, dan kewajiban pokok pengangkut adalah sebagai berikut ${ }^{12}$ :

1. Menyelenggarakan pengangkutan barang atau penumpang dari tempat pemuatan sampai di tempat tujuan dengan selamat;

2. Merawat, menjaga, memelihara barang atau penumpang yang diangkut sebaik-baiknya;

3. Menyerahkan barang yang diangkut kepada penerima dengan lengkap, utuh, tidak rusak, atau tidak terlambat;

Kewajiban-kewajiban ini sesuai dengan ketentuan pasal 186 UULLAJ tentang Lalu Lintas dan Angkutan Jalan selanjutnya disebut UULLAJ. Pada umumnya apabila pengangkut lalai dalam penyelenggaraan pengangkutan yang menjadi kewajibannya, sehingga menimbulkan kerugian bagi pengirim atau penerima barang ia bertanggunggungjawab membayar ganti kerugian sebagaimana yang diatur dalam pasal 188 UULLAJ.

Berlakunya UULLAJdiharapkan dapat membantu mewujudkan kepastian hukum ${ }^{2}$ bagi pihak-pihak yang terkait dengan penyelenggaraan jasa angkutan, baik itu perusahaan angkutan maupun pekerja (Pengemudi). Dalam hal kewajiban para pihak dalam perjanjian pengangkutan diatur dalam pasal 186 UULLAJyang menyebutkan Perusahaan angkutan umum wajib mengangkut orang dan /atau barang setelah disepakati perjanjian angkutan dan /atau dilakukan pembayaran biaya angkutan oleh penumpang dan /atau pengirim barang.

Pada pasal 191 UULLAJ juga ditegaskan bahwa Perusahaan angkutan umum bertanggung jawab atas kerugian yang di akibatkan oleh segara perbuatan orang yang dipekerjakan dalam kegiatan penyelenggaraan angkutan. Dan pasal 1367 KUHPerdata juga disebutkan bahwa Seorang tidak saja bertanggung jawab untuk kerugian yang disebabkan perbuatannya sendiri, tetapi juga untuk kerugian yang disebabkan perbuatan orang-orang yang menjadi tanggungannya atau yang disebabkan barang-barang yang berada di bawah pengawasannya.

CV Belawan Indah sebagai perusahaan yang bergerak dalam bidang jasa pengangkutan barang menerima suatu barang dari orang atau perusahaan yaitu pihak pengirim, selanjutnya bertanggung jawab untuk menyelenggarakan pengangkutan atau selanjutnya bertanggung jawab untuk mengirim barang ketempat yang dituju dengan selamat. Artinya CV Belawan Indah bertanggung jawab atas keselamatan barang dan keamanan barang yang harus diangkutnya, mulai saat diterimanya hingga saat diserahkannya barang tersebut ke tangan penerima. Serta apabila dalam pengangkutan barang tersebut berjalan tidak selamat, misalnya barang tersebut mengalami kerugian akibat kehilangan, kerusakan atau keterlambatan dalam pengirimannya, maka maka hal ini juga menjadi tanggung jawab perusahaan angkutan dan pengemudi.

Dalam hal ini CV Belawan Indah sebagai Perusahaan Angkutan umum juga tidak luput dari permasalahan yang timbul akibat kesalahan pengemudi dan perusahaan angkutan. Masalah yang kemudian timbul ialah bagaimana tanggung jawab pengemudi dan perusahaan

\footnotetext{
${ }^{1}$ Abdulkadir Muhammad, 1991 Hukum Pengangkutan Darat,Laut,Dan Udara,Bandung:Citra Aditya Bakti Hlm 1 12 Andi Astriyani Mattanang, Aspek Hukum Perjanjian Terhadap Jasa Angkutan Umum Darat, Jurnal Ilmu Hukum Legal Opinion, Voulume 3 No 2 Tahun 2013

${ }^{2}$ Simamora, Janpatar., Tafsir Makna Negara Hukum dalam Perspektif Undang-Undang Dasar Negara Republik Indonesia Tahun 1945, Jurnal Dinamika Hukum FH Universitas Jenderal Soedirman, Vol. 14 No. 3 September 2014, hlm. 547-561
} 
Jurnal Magister Hukum Program Pascasarjana Universitas HKBP Nommensen

Volume 02 Nomor o2 Juli 2021 Halaman. 181-192 e-ISSN: 2723-164X p-ISSN: 2722-9858

http://ejournal.uhn.ac.id/index.php/opinion

angkutan atas kerugian dalam pengangkutan barang melalui angkutan darat dan bagaimana upaya pemilik barang atas kerugian dalam pengangkutan barang.

\section{B. Metode Penelitian}

Dalam penulisan hukum ini penelitian dilakukan dengan membatasi ruang lingkup penelitian pada peraturan perundang- undangan yang berlaku, seperti Undang-Undang Nomor 22 Tahun 2009 tentang Lalu Lintas Dan Angkutan Jalan, Kitab Undang Undang Hukum Perdata, Kitab Undang Undang Hukum Dagang, UU No. 8 Tahun 1999 tentang Perlindungan Konsumen dan pendapat pendapat para pakar hukum melalui tulisan tulisan, jadi ruang lingkup penelitian ini adalah mengenai Tanggung Jawab Pengemudi dan Perusahaan angkutan atas kerugian dalam pengangkutan barang melalui darat dan upaya pemilik barang atas kerugian dalam pengangkutan barang dan upaya pemilik barang apabila pengemudi dan perusahaan pengangkutan tidak membayarkan ganti kerugian dalam pengangkutan barang melalui angkutan darat.

\section{Pembahasan}

\section{Tanggungjawab Pengemudi dan Perusahaan Angkutan Atas Kerugian Tanggungjawab Pengemudi CV Belawan Indah}

Pengemudi adalah orang yang mengemudikan kendaraan bermotor di jalan baik berdiri sendiri maupun karyawan atau pekerja dari perusahaan angkutan yang telah memiliki surat izin mengemudi. ${ }^{3}$ Perjanjian kerja/ kemitraan merupakan dasar dari timbulnya hak dan kewajiban antara pihak perusahaan pengangkut dan pengemudi dalam menyelenggarakan pengangkutan yang dimana pengemudi mengikatkan dirinya dibawah perintah perusahaan angkutan untuk suatu waktu tertentu, melakukan pekerjaan dengan menerima upah.

CV. Belawan Indah melakukan perjanjian kerja terhadap pengemudi dengan menggunakan sistem borongan. Pasal 1601 huruf b KUHPerdata menjelaskan bahwa perjanjian pemborongan kerja adalah bahwa pihak kesatu yaitu pemborong, mengikatkan diri untuk menyelesaikan suatu pekerjaan bagi pihak lain, yaitu pemberi tugas dengan harga yang telah ditentukan.

Tanggung jawab pengemudi dapat dilihat dari perjanjian kemitraan yang dilakukan oleh pengemudi dan perusahaan angkutan. Adapun yang menjadi tanggungjawab pengemudi $\mathrm{CV}$. Belawan Indah ialah bertanggungjawab atas keselamatan dokumen dan atau surat berharga yang melekat pada kendaraan yang dikendarai seperti Surat tanda nomor kendaraan, Buku KIR (Kartu Uji Berkala Kendaraan Bermotor ), Kartu ijin usaha, dan Surat jalan, bertanggung jawab membawa dan menjaga keselamatan barang sesuai dengan sistem, prosedur dan peraturan yang ditetapkan oleh perusahaan angkutan serta bertanggung jawab memenuhi kewajibannya yang lain sebagaimana yang telah diperjanjikan dalam perjanjian kemitraan.

Salah satu kewajiban dari pengemudi dalam perjanjian kerja/kemitraan ialah kewajiban untuk membayar ganti rugi akibat kelalaiannya yang menimbulkan keterlambatan, kerusakan dan kehilangan barang dalam penyelengaraan pengangkutan barang. Rio Nando Sirait selaku staff CV.Belawan Indah bagian savety mengatakan bahwa tanggung jawab pengemudi dimulai pada saat barang sudah dimuat dalam truck gandeng atau alat angkutan, setelah selesai

${ }^{3} \mathrm{H}$ zaeni Asyhadie, Op.cit hlm 212 
melalui proses pengecekan dan lain sebagainya dan barang telah savety atau aman sesuai dengan SOP yang berlaku maka barang akan dikirimkan. ${ }^{4}$

Apabila adanya kerusakan, keterlambatan, dan kehilangan barang yang disebabkan oleh kelalaian pengemudi dalam mengangkut barang maka hal pertama yang dilakukan adalah melakukan pelaporan kepada management perusahaan, bagian savety dan mandor yg selanjutnya akan ditangani oleh HRD dan Humas, humas akan berkoordinasi dengan kepolisian dalam pembuatan berita acara pemeriksaan pengemudi atas peristiwa akibat kecelakaan mengakibatkan rusaknya barang ataupun perbuatan melawan hukum yang dilakukan oleh pengemudi karena adanya kehilangan barang, lalu HRD akan membuat berita acara kerusakan, keterlambatan atau kehilangan barang, kemudian barang akan dievakuasi masuk ke gudang penyimpanan barang.

Michael Manurung selaku staff Humas di CV. Belawan Indah mengatakan setiap kronologi terjadi kerusakan barang, keterlambatan barang, dan kehilangan barang akan dianalisa, bahwa benar atau tidaknya pengemudi yang melakukan kelalaian atau adanya keadaan yang tidak dapat dicegah. ${ }^{5}$

Adapun mengenai jumlah kerugian yang harus dibayarkan oleh pengemudi kepada perusahaan atas kelalaiannya tersebut telah diatur dalam perjanjian kemitraan yang telah di sepakati para pihak yaitu apabila kerugian yang ditimbulkan akibat kelalaian pengemudi maka semua biaya yang timbul menjadi beban pengemudi sebesar $80 \%$ dari kerugian barang, apabila kerugian yang ditimbulkan bukan karena kelalaian pengemudi maka beban yang ditanggung oleh pengemudi sebesar $50 \%$ dari kerugian barang.

Mekanisme pembayaran ganti kerugian atas barang kepada perusahaan yaitu dapat membayarkan secara keseluruhan kerugian dan apabila tidak sanggup membayar perusahaan akan melakukan pemotongan gaji/ perincian setiap kali supir melaksanakan pengangkutan, sebab sistem pengupahan yang digunakan terhadap pengemudi oleh CV.Belawan indah ialah pembayaran upah setiap kali adanya pengangkutan yang dilakukan oleh pengemudi.

\section{Tanggungjawab CV Belawan Indah}

Tanggung jawab adalah sesuatu yang timbul karena adanya hubungan hukum sehingga menimbulkan adanya hak dan kewajiban bagi pihak - pihak terkait. Adapun Tanggung jawab perusahaan angkutan dimulai dari adanya perjanjian pengangkutan antara pengangkut dengan pengirim, lalu adanya penyerahaan barang kepada perusahaan angkutan hingga barang tersebut sampai dengan selamat ke tempat tujuan. Dalam proses pengangkutan barang, CV Belawan Indah menyelenggarakan pengangkutannya sesuai dengan prosedur yang berlaku.

Bapak Rindu Sitohang selaku HRD dan Manager mengatakan bahwa prosedur pengangkutan barang di CV Belawan Indah yaitu dimulai dari adanya perjanjian antara perusahaan dengan pengirim barang yaitu berupa perjanjian kerja sama dengan badan hukum maupun perseorangan yang dapat dibuktikan dengan dokumen pengangkutan, yang berisikan nomor barang, banyaknya unit barang, ukuran barang, harga tarif barang serta tujuan pengiriman barang. ${ }^{6} \mathrm{Hal}$ ini juga diatur dalam pasal 168 ayat 2 UULLAJ yang berbunyi "Perusahaan angkutan umum yang mengangkut barang wajib membuat surat perjanjian pengangkutan barang".

\footnotetext{
${ }^{4}$ Wawancara dengan bapak Rionando Sirait selaku staff bagian Savety di CV Belawan Indah pada Hari senin 19 Juli 2020 pukul o8.0o WIB

${ }^{5}$ Wawancara dengan bapak Michael Manurung selaku Staff Humas di CV Belawan Indah pada hari rabu 1 Juli 2020 Pukul 11.oo WIB

${ }^{6}$ Wawancara dengan bapak Rindu Sihotang selaku HRD dan Manager di CV Belawan indah pada Hari senin 28 Juni 2020 pukul 11.0o WIB
} 
Jurnal Magister Hukum Program Pascasarjana Universitas HKBP Nommensen

Volume 02 Nomor 02 Juli 2021 Halaman. 181-192 e-ISSN: 2723-164X p-ISSN: 2722-9858

http://ejournal.uhn.ac.id/index.php/opinion

Selanjutnya, ada tiga (3) tahapan yang dilakukan dalam penyelenggaraan pengangkutan melalui darat yaitu:

Pertama, Tahapan Pemuatan Barang

Pada tahapan ini pihak pengirim menyerahkan barang kepada CV. Belawan Indah serta melunasi biaya pengangkutan yang telah disepakati, dan CV. Belawan Indah menerbitkan dokumen pengangkutan sebagai bukti telah terjadinya perjanjian pengangkutan serta bukti penyerahan barang. Perusahaan Angkutan Umum yang mengangkut barang wajib membuat surat muatan barang sebagai bagian dokumen perjalanan (pasal 166 UULLAJ).

Setelah pengirim menyerahkan barang ke CV.Belawan Indah, barang tersebut akan di evaluasi kembali, apabila barang tersebut merupakan barang yang memiliki tingkat resiko yang tinggi maka barang tersebut akan diasuransikan. Sebagaimana yang diatur dalam pasal 189 UULLAJ bahwa perusahaan angkutan wajib mengasuransikan tanggunggung jawabnya sebagaimana dimaksud dalam pasal 188. Asuransi merupakan perjanjian dengan mana seseorang penanggung mengikatkan diri kepada seseorang tertanggung dengan menerima suatu premi, untuk memberikan penggantian kepadanya karena suatu kerugian, kerusakan atau kehilangan keuntungan yang diharapkan mungkin akan diseritanyakareana suatu peristiwa tak tertentu (pasal 246 KUHD).

Rionando Sirait selaku pegawai CV. Belawan Indah bagian savety mengatakan Selanjutnya barang akan dimuat ke dalam kendaraan yang di angkut, dengan memperhatikan dimensi ukuran barang sesuai dengan SOP (Standart Operasional Prosedur) dan adanya survey jalan untuk memperhatikan keselamatan pengangkutan barang, baik dalam perjalanan jarak jauh maupun jarak dekat menggunakan alat pengangkutan. Jadi kemungkinan adanya kerugian dalam pengangkutan barang yang dilakukan oleh CV. Belawan Indah sangat kecil sebab setiap pengangkutan yang dilakukan melalui proses yang sangat ketat, dan menerapkan prinsip kehati- hatian. ${ }^{7}$

Apabila pada saat pengecekan barang terdapat kerusakan barang maka akan di simpan terlebih dahulu lalu melaporkan ke bagian marketing untuk disampaikan kepada pengirim/penerima barang dengan menunjukkan bukti gambar kerusakan barang. Selanjutnya berdasarkan kesepakatan antara penerima/pengirim barang dengan pihak marketing perusahaan, terdapat beberapa upaya yang dilakukan yaitu barang akan tetap dikirim dengan kondisi kerusakan tersebut atau dilakukannya perbaikan terlebih dahulu lalu barang dikirimkan atau barang di kembalikan kepada pengirim. Dalam hal ini baik biaya perbaikan maupun biaya pengembalian barang ke pengirim atau toko yang bersangkutan dengan ongkos pengembalian yang di tanggung oleh pengirim barang.

Alat pengangkutan yang digunakan oleh CV. Belawan Indah terdiri dari Truck, Prime Mover Trailer, dan Chassis, tergantung pada barang apa yang akan di angkut. Alat pengangkutan yang digunakan untuk mengangkut barang haruslah memenuhi persyaratan yang telah ditentukan oleh Undang-undang sebagaimana yang di tentukan dalam pasal 48 UULLAJ. Setelah pemuatan selesai barang akan diantarkan oleh supir sesuai dengan waktu dan tujuan yang telah ditentukan.

Kedua, Tahap Pelaksanaan Angkutan

Dalam tahap ini barang akan dikirimkan sesuai dengan waktu dan tujuan yang telah ditentukan, dan setiap kali ada pengiriman barang melalui CV.Belawan Indah maka akan di monitor dan dipantau secara ketat oleh pos pemantauan disepanjang rute pengiriman untuk keselamatan dan kelancaran pengangkutan barang.

\footnotetext{
${ }^{7}$ Wawancara dengan bapak Rionando Sirait selaku staff bagian Savety di CV Belawan Indah pada Hari senin 19 Juli 2020 pukul o8.0o WIB
} 
Untuk keselamatan dan kelancaran pengangkutan barang, CV. Belawan Indah menetapkan beberapa persyaratan yang harus dipenuhi oleh pengemudi dalam mengangkut barang yaitu sehat jasmani dan rohani, memiliki kepribadian yang baik, memiliki kecakapan dalam mengemudikan kendaraan, memiliki surat izin mengemudi sebagaimana yang diatur dalam pasal 77 UULLAJ, dan tidak memakai obat - obatan terlarang yang dibuktikan dengan adanya test narkotika. Selanjutnya perusahaan akan memberikan Surat Tanda Nomor kendaraan, Buku KIR, Kartu Ijin Usaha dan Surat Jalan dalam menyelenggarakan pengangkutannya.

Pasal 90 ayat 1 UULLAJ menyebutkan bahwa setiap perusahaan Angkutan Umum wajib mematuhi dan memberlakukan ketentuan mengenai waktu kerja, waktu istirahat, dan pergantian Pengemudi Kendaraan Bermotor Umum sesuai dengan ketentuan peraturan perundangundangan. Dalam hal ini CV. Belawan Indah juga memberlakukan ketentuan tersebut kecuali apabila menggunakan sistem borongan berdasarkan tujuan/trayek/komisirit yang telah ditetapkan oleh perusahaan sebagaimana yang telah di dicantumkan dalam perjanjian kemitraan antara pengemudi dan perusahaan.

Pengangkutan yang dilakukan oleh CV.Belawan Indah tentunya bukan hanya angkutan barang umum namun ada beberapa barang barang khusus.Pasal 162 UULLAJ mengatur beberapa persyaratan yang wajib dilakukan apabila pengangkut mengangkut barang khusus yaitu:

(1) Kendaraan Bermotor yang mengangkut barang khusus wajib:

1. memenuhi persyaratan keselamatan sesuai dengan sifat dan bentuk barang yang diangkut;

diberi tanda tertentu sesuai dengan barang yang diangkut;

memarkir Kendaraan di tempat yang ditetapkan; d membongkar dan memuat barang di tempat yang ditetapkan dan dengan menggunakan alat sesuai dengan sifat dan bentuk barang yang diangkut;

beroperasi pada waktu yang tidak mengganggu Keamanan, Keselamatan, Kelancaran, dan Ketertiban Lalu Lintas dan Angkutan Jalan; dan f. mendapat rekomendasi dari instansi terkait.

(2) Kendaraan Bermotor Umum yang mengangkut alat berat dengan dimensi yang melebihi dimensi yang ditetapkan sebagaimana dimaksud dalam Pasal 19 harus mendapat pengawalan dari Kepolisian Negara Republik Indonesia.

(3) Pengemudi dan pembantu Pengemudi Kendaraan Bermotor Umum yang mengangkut barang khusus wajib memiliki kompetensi tertentu sesuai dengan sifat dan bentuk barang khusus yang diangkut.

Tiga, Tahap Penyerahan barang atau pemongkaran barang

Pada tahap ini apabila kendaraan bermotor atau truck tiba, barang langsung di antarkan ke tempat tujuan dan diserahkan kepada penerima sebagaimana yang telah disepakati dalam perjanjian dan tertera pada dokumen pengangkutan. Apabila ada komplain dari penerima barang atas kerusakan barang, CV. Belawan Indah memberikan tenggang waktu selama 3 hari, untuk pengembalian barang dihitung setelah adanya penyerahan barang. Kemudian akan di evaluasi atau dilakukan pemeriksaan, apabila kerusakan barang merupakan kesalahan dari pengangkut maka perusahaan akan bertanggung jawab atas kerusakan barang tersebut. ${ }^{8}$

Setiap penyelenggaraan pengangkutan tentunya tidak pernah lepas dengan adanya resiko baik dilakukan dengan sengaja maupun tidak sengaja yang menimbulkan kerugian. Konsep tanggung jawab merupakan dasar penyelesaian ganti rugiapabila adanya kerugian

\footnotetext{
${ }^{8}$ Wawancara dengan bapak Rionando Sirait selaku staff bagian Savety di CV Belawan Indah pada Hari senin 19 Juli 2020 pukul o8.oo WIB
} 
dalam pengangkutan barang. Dalam hal ini hukum pengangkutan mengenal tiga prinsip tanggung jawab yaitu tanggung jawab karena kesalahan (fault liability), tanggung jawab karena praduga (presumtion liability), dan tanggung jawab mutlak (absolute liability). Hukum pengangkutan indonesia pada umumnya menganut prinsip tanggung jawab praduga dan tanggung jawab karena kesalahan.

Prinsip Tanggung jawab berdasarkan kesalahan

Menurut prinsip ini setiap pengangkut yang melakukan kesalahan dalam penyelengaraan pengangkutan harus bertanggungjawab membayar ganti kerugian atas segala kerugian yang timbul akibat dari kesalahannya itu. Perusahaan angkutan wajib mengangkut barang setelah disepakati perjanjian pengangkutan dan dilakukannya pembayaran biaya pengangkutan. Tanggung jawab terhadap pengirim barang dimulai sejak adanya penyerahan barang dan diterimanya barang sampai diserahkannya barang kepada penerima barang. $\mathrm{CV}$. Belawan Indah bertanggung jawab atas kerugian yang diderita oleh pengirim barang karena musnah, hilang atau rusaknya barang akibat kesalahan pengangkut dalam penyelenggaran pengangkutan.

Prinsip Tanggung Jawab berdasarkan praduga

Menurut prinsip ini pengangkut dianggap selalu bertanggungjawab atas kerugian yang timbul dari pengangkutan yang diselenggarakannya. Tetapi jika pengangkut dapat membuktikan bahwa ia tidak bersalah, maka ia dibebaskan dari kewajiban membayar ganti rugi.

Prinsip Tanggung jawab mutlak

Menurut prinsip ini pengangkut harus bertanggung jawab membayar ganti kerugian terhadap setiap kerugian yang timbul dari pengangkutan yang diselenggarakan tanpa keharusan pembuktian ada tidaknya kesalahan pengangkut. Hukum pengangkutan indonesia pada umumnya menganut prinsip tanggung jawab praduga dan tanggung jawab karena kesalahan. Prinsip tanggung jawab pengangkutan ini selaras dengan ketentuan perundangundangan mengenai pengangkutan yang di atur dalam UULLAJ pasal 188 yang memberikan ketentuan bahwa perusahaan angkutan umum wajib mengganti kerugian yang diderita oleh penumpang atau pengirim barang karena lalai dalam melaksanakan angkutan.

Ketentuan lainnya diatur dalam UULLAJ pasal 193 ayat 1 yang mengatakan bahwa Perusahaan Angkutan Umum bertanggung jawab atas kerugian yang diderita oleh pengirim barang karena barang musnah, hilang, atau rusak akibat penyelenggaraan angkutan, kecuali terbukti bahwa musnah, hilang, atau rusaknya barang disebabkan oleh suatu kejadian yang tidak dapat dicegah atau dihindari atau kesalahan pengirim.

Adapun bentuk - bentuk kerugian yang terdapat di CV. Belawan Indah ialah ganti rugi materil yaitu kerugian yang bersifat kebendaan meliputikerugian atas keterlambatan pengiriman barang, kerusakan barang, dan kehilangan barang.Apabila terdapat kerugian dalam penyelenggaraan pengangkutan di CV. Belawan Indah maka hal pertama yang dilakukan ialah mengevaluasi kondisi tersebut. Apabila adanya keterlambatan penyerahan barang, CV belawan indah akan memberitahukan pihak penerima barang bahwasanya terjadi keterlambatan, dan meminta pengertian kepada penerima dan pengirim barang. Adapun kerugian yang timbul atas keterlambatan barang adalah tanggung jawab perusahaan angkutan.

Apabila kerugian yang yang ditimbulkan dikarenakan adanya kerusakan barang dan karena adanya kehilangan barang, maka keadaan tersebut akan dievaluasi dan dilakukan pemeriksaan, namun terlebih dahulu menyampaikan kepada pengirim bahwa adanya kehilangan pada barang atau adanya kerusakan pada barang dan meminta pengertian kepada pengirim/penerima barang. Selanjutnya proses evaluasi dilakukan dengan cara mengamankan sisa barang (kembali ke gudang penyimpanan), membuat laporan kepolisian, mengintrogasi 
pengemudi sebagai membuat berita acara pemeriksaan. Apabila terbukti bahwa kerusakan barang atau kehilangan barang tersebut merupakan murni kesalahan pengemudi maka ganti kerugian ditanggung secara bersama-sama oleh perusahaan dan pengemudi sebagaimana yang telah tercantum dalam perjanjian kemitraan antara pengemudi dan perusahaan. Hal tersebut diatur dalam pasal 191 UULLAJ yang menyebutkan bahwa perusahaan angkutan umum bertanggungjawab atas kerugian yang di akibatkan oleh segala perbuatan orang yang dipekerjakan dalam penyelengaraan pengangkutan.

CV. Belawan Indah bertanggung jawab terhadap pengirim/penerima dan mengganti semua kerugian yang ditimbulkan apabila dalam tahap evaluasi dan pemeriksaan terbukti bahwa kerugian barang yang di timbulkan ialah kesalahan daripada pihak pengangkut maupun disebabkan oleh pengemudi.Kesalahan disini adalah terjemahan dari " schuld" yang meliputi kelalaian dan kesengajaan yang menimbulkan kerugian. ${ }^{9} \mathrm{CV}$ Belawan Indah akan langsung membayar kerugian yang diderita oleh penerima/ pengirim barang.

$\mathrm{CV}$. Belawan Indah juga bertanggung jawab atas setiap pengangkutan yang diselenggarakannya terhadap pengirim/penerima dan mengganti semua kerugian yang ditimbulkan apabila dalam tahap evaluasi dan pemeriksaan terbukti bahwa kerugian barang yang di timbulkan ialah kesalahan daripada pihak pengangkut. Kecuali adanya keadaan memaksa sebagaimana yang diatur dalam pasal 91 KUHD dan pasal 1245 KUHPerdata. Hal inilah yang menjadi keunggulan dari CV. Belawan Indah yaitu memberikan kepercayaan kepada pengirim/penerima atas jasa pengangkutan yang disediakan.

Besaran ganti kerugian yang tanggung oleh CV.Belawan Indah akan dinegosiasikan terhadap Penerima/ pengirim baranga ataupun tergantung pada perjanjian yang disepakati pada awalnyatetapi biasanya dihitung dari kerusakan yang dialami dan kehilangan yang dialami secanya nyata dialami oleh penerima/ pengirim barang yang dibayarkan secara tunai. Namun apabila kerusakan barang yang timbul masih dapat diperbaiki maka barang akan di simpan ke gudang penyimpanan CV. Belawan Indah untuk dilakukan perbaikan kerusakan.

Namun adapun pengecualian tanggungjawab atas tuntutan ganti rugi terhadap perusahaan angkutan ialah apabila pengangkut dalam menyelengarakan pengangkutannya dengan mengendalikan alat pengangkuatannya dengan profesional dan kehati hatian yang tinggi kemudian terjadi kecelakaan atau adanya kejadian atau musibah yaitu berupa peristiwa yang tidak dapat dicegah atau diperkirakan.

\section{Upaya Penyelesaian Sengketa}

\section{Penyelesaian Sengketa Melalui BPSK (Badan Penyelesaian sengketa konsumen)}

Pelaksanaan pengangkutan barang melalui darat tidak terlepas dari adanya sengketa, sengketa berawal dari adanya ketidakpuasan dari salah satu pihak ${ }^{10}$ karena adanya pihak lain yg tidak memenuhi prestasi sebagaimana yang telah disepakati para pihak dalam perjanjian. Siapakah yang semestinya antara penerima dan pengirim yang dapat dikatakan sebagai pemilik barang yang dapat menderita kerugian atas tidak terlaksananya perjanjian pengangkutan, pertama-tama tergantung dari faktor, apakah penerima telah melahirkan kehendaknya untuk menerima barang angkutan, diluar hal ini pengirimlah yang dapat bertindak sebagai pemilik barang untuk menuntut penggantian kerugian,karena itu segala sesuatu tergantung dari hubungan- intern antara pengirim dan penerima. Dengan demikian pengirim dan penerima dapat bertindak sebagai pemilik barang yang memiliki hak untuk

\footnotetext{
9 J. Satrio, Hukum Perikatan Perikatan Pada Umumnya Cet 1, Bandung Penerbit Alumni hlm 90

${ }^{10}$ Simamora, Janpatar., Problematika Penyelesaian Sangketa Kewenangan Lembaga Negara oleh Mahkamah Konstitusi, Jurnal Mimbar Hukum Fakultas Hukum Universitas Gadjah Mada Yogyakarta, Volume 28, Nomor 1, Februari 2016, hlm. 77-92.
} 
menuntut penggantian kerugian. Sengketa pengangkutan timbul karena adanya kerugian yang dialami oleh penerima/pengirim barang sebagai pemilik barang, kerugian yang dialami oleh pemilik barang dapat berupa keterlambatan, kerusakan barang dan kehilangan barang.

Upaya pemilik barang atas kerugian dalam pengangkutan barangdengan mengajukan tuntutan ganti rugi. Tuntutan ganti rugi terhadap pengangkut oleh pihak penerima/pengirim dalam perselihan-perselisihan didasarkan pada perjanjian pengangkutan, yang ditetapkan yang ternyata tidak melaksanakan perjanjian itu secara wajar dan didalam waktu yang di tetapkan, tidak pula berhasil mendiskulpir dirinya, maka sudah barang tentu penerima/pengirim pihak dapat menuntut penggantian kerugian yang diderita, hak menuntut mana terbit dari perjanjian pengangkutan tersebut sebagai demikian ${ }^{11}$

Dasar dari upaya perlindungan hukum terhadap pemilik barang apabila pengemudi dan perusahaan angkutan tidak membayarkan ganti kerugian dalam pengangkutan barang melalui darat dapat dilihat pada pasal 4 ayat 5 dan 8 dan pasal 7 huruf $\mathrm{f}$ Undang-Undang No 8 Tahun 1999 tentang perlindungan konsumen. Pasal 4 ayat 5 menegaskan bahwa "Konsumen berhak untuk mendapatkan advokasi, perlidungan, dan upaya penyelesaian sengketa perlindungan konsumen secara patut;" Pasal 4 ayat 8 "Konsumen berhak untuk mendapatkan kompensasi, ganti rugi dan/atau penggantian, apabila barang dan/atau jasa yang diterima tidak sesuai dengan perjanjian atau tidak sebagaimana mestinya;" pasal 7 huruf $\mathrm{f}$ " bahwa pelaku usaha berkewajiban untuk memberi kompensasi, ganti rugi dan/atau penggantian atas kerugian akibat penggunaan, pemakaian dan pemanfaatan barang dan/atau jasa yang diperdagangkan“.

Dari uraian pasal diatas dapat dilihat adanya kewajiban pelaku usaha untuk memberikan ganti rugi atas kerusakan dan kehilangan barang yang diakibatkan oleh pelaku usaha, dan konsumen berhak untuk mendapatkan ganti rugi tersebut. Namun apabila pelaku usaha tidak memenuhi kewajibannya sehingga menimbulkan perselisihan, Pasal 45 UU No 8 tahun 1999 tentang Perlindungan Konsumen juga menegaskan bahwa:

(1) Setiap konsumen yang dirugikan dapat menggugat pelaku usaha melalui lembaga yang bertugas menyelesaikan sengketa antara konsumen dan pelaku usaha atau melalui peradilan yang berada di lingkungan peradilan umum.

(2) Penyelesaian sengketa konsumen dapat ditempuh melalui pengadilan atau di luar pengadilan berdasarkan pilihan sukarela para pihak yang bersengketa.

(3) Penyelesaian sengketa di luar pengadilan sebagaimana dimaksud pada ayat (2) tidak menghilangkan tanggungjawab pidana sebagaimana diatur dalam Undang-undang.

(4)Apabila telah dipilih upaya penyelesaian sengketa konsumen di luar pengadilan, gugatan melalui pengadilan hanya dapat ditempuh apabila upaya tersebut dinyatakan tidak berhasil oleh salah satu pihak atau oleh para pihak yang bersengketa.

Dari uraian pasal 45 dapat dilihat bahwa penyelesaian sengketa ganti kerugian dapat ditempuh secara litigasi (pengadilan) dan penyelesaian sengketa non litigasi (luar pengadilan). Para pihak yang bersengketa diberikan pilihan untuk menentukan penyelesaian sengketa yang akan di tempuh, namun penyelesaian sengketa non litigasi (luar pengadilan) diupayakan terlebih dahulu sebelum para pihak memilih untuk menyelesaikan sengketa melalui litigasi (pengadilan), mengingat proses yang di tempuh melalui pengadilan cukup lama dan membutuhkan biaya yang banyak.

BPSK (Badan Penyelesaian sengketa konsumen) adalah lembaga penyelesaian sengketa di luar pengadilan yang dibentuk oleh pemerintah pada setiap daerah tingkat II untuk

\footnotetext{
${ }^{11}$ R Soekardono, Hukum Dagang Indonesia Jilid II 1981, Jakarta Penerbit Rajawali hlm 36
} 
menyelesaikan sengketa pelaku usaha dan konsumen. Adapun tugas dan wewenang BPSK yaitu diatur dalam pasal 52 UU No 8 tahun 1999 tentang Perlindungan Konsumen yaitu :

a. Melaksanakan penanganan dan penyelesaian sengketa konsumen, dengan cara melalui mediasi atau arbitrase atau konsiliasi;

b. Memberikan konsultasi perlindungan konsumen;

c. Melakukan pengawasan terhadap pencantuman klausula baku;

d. Melaporkan kepada penyidik umum apabila terjadi pelanggaran ketentuan dalam undang-undang ini;

e. Menerima pengaduan baik tertulis maupun tidak tertulis, dari konsumen tentang terjadinya pelanggaran terhadap perlindungan konsumen;

f. Melakukan penelitian dan pemeriksaan sengketa perlindungan konsumen;

g. Memanggil pelaku usaha yang diduga telah melakukan pelanggaran terhadap perlindungan konsumen;

h. Memanggil dan menghadirkan saksi, saksi ahli dan/atau setiap orang yang dianggap mengetahui pelanggaran terhadap undang-undang ini;

i. Meminta bantuan penyidik untuk menghadirkan pelaku usaha, saksi, saksi ahli, atau setiap orang sebagaimana dimaksud pada huruf g dan huruf $h$, yang tidak bersedia memenuhi panggilan badan penyelesaian sengketa konsumen;

j. Mendapatkan, meneliti dan/atau menilai surat, dokumen, atau alat bukti lain guna penyelidikan dan/atau pemeriksaan;

k. Memutuskan dan menetapkan ada atau tidak adanya kerugian di pihak konsumen;

1. Memberitahukan putusan kepada pelaku usaha yang melakukan pelanggaran terhadap perlindungan konsumen;

m. Menjatuhkan sanksi administratif kepada pelaku usaha yang melanggar ketentuan undang-undang ini.

Sebagaimana yang diatur dalam pasal 52 ayat 2 bahwa BPSK melaksanakan penanganan dan penyelesaian sengketa konsumen dengan cara : ${ }^{12}$

Abitrase

Adalah proses penyelesaian yang dilakukan dalam wadah arbitraltribunal (majelis arbitrase), para pihak melalaui klausul yang disepakati dalam perjanjian, menindukkan diri (submission) menyerahkan penyelesaian sengketa yang timbul dari perjanjian keda pihak ketiga yang netral dan bertindak sebagai arbiter.

Mediasi

Adalah negosiasi yang melibatkan pihak ketiga yaitu mediator yang memiliki kealian prosedur mediasi yang efektif, dapat membantu dalam situasi konflik untuk mengkoordinasikan aktivitas mereka sehingga lebih efektif dalam proses tawar menawar, bila tidak ada negosiasi tidak ada mediasi.

Konsiliasi

Adalah lanjutan dari mediasi, mediator berubah fungsi menjadi konsiliator. Dalam hal ini konsiliasi berwenang menyusun dan merumuskan penyelesaian untuk ditawarkan kepada pihak. Jika para pihak dapat menyetujui, solusi yang dibuat konsiliator menjadi resolution.

Permohonan penyelesaian sengketa kepada BPSK dapat diajukan secara tertulis maupun tidak tertulis beserta bukti bukti pendukung alasan pengaduan selanjutnya akan dicatat oleh Sekretariat BPSK yang dibubuhi tanggal dan nomor registrasi, apabila data pengaduan diperiksa benar dan lengkap, ketua pengadilan akan membuat surat panggilan kepada tergugat agar hadir pada sidang pertama. Apabila proses penyelesaian sengketa melalui BPSK berhasil,

\footnotetext{
${ }^{12}$ Nurnaningsih hlm 20- 34 
maka putusan BPSK dimintakan penetapan eksekusi pada Pengadilan Negeri tempat konsumen dirugikan. Para pihak wajib melaksanakan isi putusan. Apabila penyelesaian sengketa di luar pengadilan tidak berhasil atau menolak putusan BPSK maka pengirim/ penerima dapat mengajukan gugatan atau keberatan kepengadilan paling lambat 14 (empat belas) hari kerja setelah menerima pemberitahuan putusan tersebut.

\section{Penyelesaian Sengketa Melalui Litigasi/Pengadilan}

Litigasi berarti penyelesaian pesengketaan atau perselisihan para pihak melalui pengadilan. Dalam perkara perdata di pengadilan terdapat dua tahap yaitutahap administratif dan tahap yudisial. Tahap administratif adalahtahap yang harus dilakukan sebelum sidang pertama, dimana yang diawali dengan pengajuan gugatan baik tertulis maupun tidak tertulis yang ditandatangani penggugat atau kuasanya yang ditujukan kepada ketua pengadilan negeri melalui panitera muda perdata. Pasal 95 KUHD mengatur bahwa segala hak untuk mengajukan gugatan terhadap pada ekspeditur, pengangkut atau juragan perahu karena hilangnya barang- barang seluruhnya atau karena rusaknya, berdaluarsa setelah tenggang waktu selama satu tahun terhadap pengiriman- pengiriman di dalam wilayah indonesia, selama dua tahun terhadap terhadap pengiriman pengiriman dari indonesia keluar tenggang waktu mana dalam hal hilangnya barang-barang, dihitung mulai saat barang-barang itu sedianya telah harus selesai diangkutnya dan dalam hal rusak atau terlambatnya disampaikan, mulai hari barang- barang itu tiba di tempat tujuannya.

Setelah gugatan dinyatakan terdaftar, dan setelah melewati proses sampai pada majelis hakim menerima berkas perkara dan mempelajari berkas perkara disinilah tahap yudisial dan para pihak akan panggil untuk menghadiri sidang dan mengikuti persidangan sampai pada akhirnya majelis hakim mengeluarkan putusan.

Penerima/pengirim dapat mengajukan permohonan pemeriksaan ekspertise jika barangbarang angkutan yang berarti jumlah dan nilainya, berhubung biaya upah yang biasanya dipinta oleh ahli- ahli tersebut. Ekspertise itu mungkin akan menghasilkan pembuktian tentang kerugian, yaity mengenai jenis dan besarnya sebagai terderita menurut kenyataankenyataan dan mungkin akan merupakan persangkaan-persangkaan tentang timbulnya kerugian itu selama perjalanan pengangkutan. Dalam pemeriksaan ekspertise tenggang waktu 2 X 24 Jam termasuk atau kemudian sama sekali tidak digunakan, maka pembuktian tersebut dapat digunakan oleh penerima, tetapi penerima masih dapat membuktikan dengan surat surat (faktur-faktur). ${ }^{13}$

Berdasarkan penelitian yang dilakukan melalui wawancara dengan bapak Rindu Sihotang SH selaku HRD di CV.Belawan Indah mengatakan bahwa CV. Belawan Indah tidak pernah menerima gugatan dari pengirim/penerima atas tidak dibayarkannya ganti kerugian oleh CV. Belawan Indah dalam pengangkutan barang melalui darat. Alasan mengapa CV. Belawan Indah tidak pernah menerima gugatan dari pengirim/penerima adalah karena CV. Belawan Indah sangat menjaga kepercayaan yang diberikan oleh pengirim kepada perusahaan untuk mengangkut barang, dan adapun apabila adanya kerugian yang ditimbulkan dari penyelenggaraan pengangkutan langsung dibayarkan oleh CV. Belawan Indah.

\section{D.Kesimpulan}

Berdasarkan pada uraian tersebut di atas, dapat ditarik kesimpulan bahwa pengemudi dan perusahaan angkutan bertanggung jawab secara bersama-sama atas kerugian yang ditimbulkan karena adanya keterlambatan, kerusakan dan kehilangan barang yang terjadi

\footnotetext{
${ }^{13}$ R Soekardono, SH, Op.cit Hlm 46 
pada setiap penyelenggaraan pengangkutan barang melalui darat yang dilakukan oleh CV.Belawan Indah apabila terbukti bahwa keterlambatan, kerusakan dan kehilangan barang disebabkan karena adanya kelalaian dari pengemudi dan perusahaan angkutan. Jumlah pengantian kerugian yang dibayarkan ialah kerugian yang nyata- nyata dialami oleh pengirim/penerima barang yang dibayarkan secara tunai. Namun apabila terbukti bahwa kerugian tersebut bukan karena kesalahan dari pengemudi dan perusahaan angkutan maka CV. Belawan indah tidak bertanggungjawab atas kerugian yang terjadi. Penerima/pengirim barang dapat mengajukan tuntutan ganti kerugian atas kerugian dalam pengangkutan barang melalui lembaga penyelesaian sengketa konsumen dan pelaku usaha atau yang disebut BPSK atau melalui peradilan yang berada di lingkungan peradilan umum. Salah satu tugas dan wewenang BPSK sebagai lembaga penyelesaian sengketa diluar pengadilan dalam melaksanakan penanganan dan penyelesaian sengketa konsumen, dengan cara melalui mediasi atau arbitrase atau konsiliasi, upaya tersebut dilakukan untuk memutuskan dan menetapkan ada atau tidak adanya kerugian di pihak konsumen, memberitahukan putusan kepada pelaku usaha yang melakukan pelanggaran terhadap perlindungan konsumen serta menjatuhkan sanksi administratif kepada pelaku usaha yang melanggar ketentuan Undang-undang No 8 Tahun 1999 tentang Perlindungan Konsumen. Namun apabila para pihak menolak putusan BPSK dapat mengajukan keberatan atau gugatan ke pengadilan.

\section{Daftar Pustaka}

Amriani, Nurnaningsih, 2012, Mediasi Alternatif Penyelesaian Sengketa Perdata Di Pengadilan, Depok:PT Raja Grafindo Persada

Asyhadie, Zaeni, 2018, Pokok Pokok Hukum Dagang, Depok:PT Raja Grafindo Persada

Muhammad, Abdulkadir, 1986, Hukum Perjanjian, Bandung : Penerbit Alumni

Abdulkadir Muhammad, 1991, Hukum Pengangkutan Darat, Laut, Dan Udara, Bandung : Citra Aditya Bakti

Satrio, 1993, Hukum Perikanan Perikatan Pada Umumnya, Bandung:Penerbit Alumni

Soekanto, Soejono, 2004, Penelitian Hukum Normatif Tinjauan Singkat, Jakarta:PT Raja Grafindo Persada

Soekardono, 1981, Hukum Dagang Indonesia, Jakarta:Penerbit Rajawali

\section{Jurnal}

Andi Astriyani Mattanang, Aspek Hukum Perjanjian Terhadap Jasa Angkutan Umum Darat, Jurnal Ilmu Hukum Legal Opinion, Voulume 3 No 2 Tahun 2013

Simamora, Janpatar., Tafsir Makna Negara Hukum dalam Perspektif Undang-Undang Dasar Negara Republik Indonesia Tahun 1945, Jurnal Dinamika Hukum FH Universitas Jenderal Soedirman, Vol. 14 No. 3 September 2014, hlm. 547-561

Simamora, Janpatar., Problematika Penyelesaian Sangketa Kewenangan Lembaga Negara oleh Mahkamah Konstitusi, Jurnal Mimbar Hukum Fakultas Hukum Universitas Gadjah Mada Yogyakarta, Volume 28, Nomor 1, Februari 2016, hlm. 77-92.

\section{Peraturan Perundang-undangan}

Kitab Undang-Undang Hukum Dagang

Kitab Undang-Undang Hukum Perdata 